International Journal of Instruction e-ISSN: 1308-1470 • www.e-iji.net

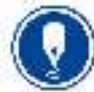

Article submission code: 20200502010655
Received: 02/05/2020

Revision: 05/10/2020
April 2021 • Vol.14, No.2

p-ISSN: 1694-609X

pp. $571-590$

Accepted: 27/10/2020

OnlineFirst: 07/02/2021

\title{
Scientific Methodology in Integrated High Schools: A Case Study
}

\section{Genaina Fernandes Guerra}

Master, The Post-Graduate Program in Professional and Technological Education-Prof EPT- Federal Goiano Institute, Brazil, genainaguerral@gmail.com

\section{Matias Noll}

Prof., The Post-Graduate Program in Professional and Technological Education-Prof EPT-Federal Goiano Institute, Brazil, matias.noll@ifgoiano.edu.br

This study evaluated how the process of teaching scientific methodology occurs in technical courses in integrated high schools. The qualitative case study was conducted through documentary analysis (based on regulations and pedagogical projects) and semi-structured interviews with teachers $(n=7)$, coordinators $(n=3)$, and students $(\mathrm{n}=16)$ of the integrated technical courses in Agriculture, Computer Science for the Internet, and Environmental Studies. The teachers and coordinators have academic backgrounds and an undergraduate degree in their specific areas, and all have a master's or doctorate degree. The students were enrolled in the $2^{\text {nd }}$ or $3^{\text {rd }}$ grade of high school and have already taken the methodology course. The research included an analysis of the pedagogical projects of technical courses and teaching plans of participating teachers. The interview data were analyzed using Bardin's content analysis technique. The results of the study showed that the scientific methodology teacher in high school is still in training. The students recognized the importance of gaining knowledge of scientific research for their academic and professional education, but reported difficulties in achieving it. Teachers also recognized these difficulties and use various teaching strategies to make student learning and productivity more flexible.

Keywords: scientific methodology, integrated secondary education, scientific training, teaching procedures, teaching

\section{INTRODUCTION}

Conducting research involves collecting data and information on a subject the researcher considers relevant (Lüdke \& André, 2017). Research means systematically obtaining answers to a given fact or phenomenon (Moreira \& Caleffe, 2011). The necessary guidelines for knowledge construction are passed on through scientific methodology, which according to Demo (2006), is one of the most planned disciplines in preparing students for research. Scientific production occurs through available knowledge and the judicious use of methods, techniques, and other scientific procedures (Gil, 2008). Here,

Citation: Noll, M., \& Guerra, G. F. (2021). Scientific Methodology in Integrated High Schools: A Case Study. International Journal of Instruction, 14(2), 571-590. https://doi.org/10.29333/iji.2021.14232a 
"methodology" encompasses the steps for conducting research and guides students in writing and presenting scientific papers.

All processes related to conducting research are objects of the study of methodology, which stimulates students' intellectual development (Moreira \& Caleffe, 2011). According to Slessarev et al. (2015), education should provide satisfactory pedagogical conditions to prepare students to conduct scientific research from a young age, and thus contribute to their professional training. Neuenfeldt et al. (2011) observed that initiation into research should prioritize the perception of science and research, work on the norms of scientific writing, and connect the investigation with students' professional areas of expertise. The basic document on Brazilian technical professional education (at the high school level) reports that the educational principle of research should contribute to the formation of individuals' intellectual autonomy and guide them in their quest to solve everyday problems (Brazil, 2007). As such, this should "be present in all school education for those who live and will live from their own work" (Brazil, 2007, p. 48). In this way, scientific training can lead to educational training when individuals are able to create their own projects from an emancipatory perspective (Demo, 2006).

Although the discipline of scientific methodology aims to encourage research and academic production, there is a distancing of students when developing such activities, partly because of how the content is taught and students' lack of affinity with the discipline (Araújo et al., 2015). In addition, students and teachers do not commit to research, which hinders the construction of knowledge (Santos, 2011). Regarding basic education for students undertaking research activities, prior preparation as well as human and material resources for teaching science are lacking (Filipecki et al., 2006). For Maia (2008), low-quality high school education prevents students from developing reasoning and critical thinking abilities, and from producing knowledge. Therefore, the authors agree that the introduction of research in schools requires changes from all involved in the process: students, teachers, researchers, and coordinators.

In this context, the teaching-learning process must be mediated through research that allows students and teachers to understand and seek answers regarding their objects of investigation (Pacheco et al., 2010). The Brazilian National Curriculum Guidelines for High School Technical Vocational Education establish that professional practice is guided by research as a pedagogical principle in overcoming learning challenges (Brazil, 2013). Thus, this research investigates the process of teaching scientific methodology in technical courses in integrated high schools in technical professional education in Brazil. To our knowledge, this is the first study to focus on this issue.

Countries such as Turkey have implemented educational actions that value and recognize the importance of research activities in schools (Tosun, 2014). Tosun (2014) clarifies that the discipline of Scientific Research Methods has become mandatory in undergraduate courses to ensure future teachers develop scientific thinking and have conditions on which to conduct scientific research, especially in the educational context. Thus, the valuation of scientific research is related to recognizing the importance of scientific activities in the development and progress of nations and their populations (Hatamleh, 2016). Learning based on research methods develops students' reasoning, 
critical thinking, and knowledge of scientific issues (Wu et al., 2016). Here, the teaching of scientific methodology improves students' professional and personal performance through basic methodological guidelines for the practice of research (Laranjeiras et al., 2011).

Therefore, the importance of this study is the possibility of promoting reflections that improve teaching disciplines related to the scientific training of students in integrated technical courses at the Federal Institute Goiano, Campus Ceres. Understanding the process of teaching scientific methodology from subjects' viewpoint contributes to expanding the discussion of the teaching and learning process underlying technical courses. Therefore, this study aimed to evaluate the process of teaching scientific methodology in technical courses in integrated high schools of the Federal Institute Goiano, Campus Ceres. The study intended to answer the following research questions: Does teaching the discipline of scientific methodology in an integrated high school contribute to the scientific training of students? What issues exist regarding the teaching and learning process?

\section{METHOD}

\section{Nature and type of research}

We employed a qualitative approach with an institutional case study. A case study involves the collection and analysis of data related to an individual, family, or group (Prodanov \& Freitas, 2013). In a qualitative study, Ferreira (2015) states that the researcher investigates social phenomena including human reality, the limitations experienced, and actions and attitudes of the subjects involved in the events. This approach is well suited to our research problem, as it seeks to analyze aspects involved in the development of the scientific methodology discipline in an integrated high school through the perception of teachers and students of technical courses. Studies in the field of education are complex phenomena that can be better studied through a qualitative approach, which allows understanding the fundamentals and worldview of the researched and researchers, respectively (Lüdke \& André, 2017).

\section{Survey participants}

The research was conducted at the Goiano Federal Institute, Campus Ceres, located in the São Patrício Valley in the region of Goiás, Brazil. The research participants were 16 students, 7 professors, and 3 coordinators, who are part of the teaching staff and students of the integrated technical courses in Agriculture, Computer Science for the Internet, and Environmental Studies at the Ceres Campus. The teachers and coordinators have academic backgrounds (undergraduate degrees) in their specific areas, and a master's or doctorate degree. Of the teachers, three teach the scientific methodology course and four teach courses for the common and vocational core. The students are enrolled in the $2^{\text {nd }}$ or $3^{\text {rd }}$ grade of high school and have already taken the methodology course.

We contacted the director of the Ceres Campus and head of the Educational Department, and received authorization to establish initial contact with the participants. 
After explaining the experiment in class, students voluntarily decided to participate in the research. Teachers and coordinators were invited to participate by e-mail or in person. Thus, the selection of participants occurred in a voluntary and random way, respecting the desire or not of each person to participate in the study. For those willing to participate, we agreed on a day, time, and place at the institution to conduct the interviews. We observed all ethical principles regarding research with human beings according to Brazilian resolution 466/12 (Brazil, 2012).

\section{Data collection procedures}

In this study, data were collected through documentary research and interviews. The documents analyzed were the regulations and pedagogical projects of the technical courses at the secondary level and teaching plans of participating teachers, which were made available on the portal of the IF Goiano (Federal Institute of Goiano: ww.ifgoiano.edu.br) through the institution's website.

The interviews were recorded and guided by a script with semi-structured questions. To ensure participants' anonymity, we identified the interviewees in their speeches using the letters T (teacher), SMT (scientific methodology teacher), C (coordinator), and S (student), followed by the number corresponding to the chronological order of the interviewee. Before each interview, we applied a questionnaire with closed questions to characterize the participants in terms of their academic background, time of performance in integrated high school, course, grade, and other relevant aspects. We used the information collected through the questionnaires to complement the interview data.

\section{Content validation}

The semi-structured script for interviews and the questionnaire were first submitted for content validation. Content validity refers to the detailed verification of the instrument content to confirm if the items included accurately portray the subject to be evaluated (Hermida \& Araújo, 2006). Validating data collection instruments is essential in ensuring the authenticity and confidentiality of the results (Medeiros et al., 2015).

The content and format of the interview questions were evaluated at another campus with participants with the same characteristics as those in the actual study: two coordinators, two teachers, and six students. The participating coordinators and professors have a doctorate in their specific areas and experience in validating qualitative instruments. The criteria to select evaluators were their free will and availability to participate in the research. The content was evaluated according to the following criteria: comprehension, flow, intelligibility, and ambiguousness (if any). All suggestions made by the participants were analyzed and incorporated in the final interview version.

\section{Quantitative validation}

The questions were scored on a scale ranging from 0 to 10 for the following established criteria: organization, objectivity, clarity, ease of reading, and understanding of the content. Thus, the evaluators judged the items of the data collection instruments relevant to and understood by the research subjects. All questions obtained scores above 8.5. We 
calculated the weighted average of the values obtained for each criterion considering the total number of evaluators. Thus, based on Hermida and Araújo (2006) and Yamada and Santos (2009), we considered the value obtained sufficient to retain the questions in the instrument.

\section{Data analysis}

The data were transcribed and analyzed through a content analysis technique, which guided the pre-analysis, exploration of the material, and treatment of the results (Bardin, 2016). Content analysis is "a set of communication analysis techniques using systematic procedures and objectives to describe the content of messages" (Bardin, 2016, p.44). By reading the interview transcripts, we identified thematic axes around which the interviewees' statements were organized.

The thematic axes identified were divided into categories according to the meaning presented. Thus, the categories were created from opinions, comments, and relevant phrases to address the research questions and objectives. Therefore, the categories are associated with the perceptions and expectations of teachers, coordinators, and students of scientific training in integrated high schools, strategies used in classes, and difficulties related to conducting research, among other emerging topics. In the documents, we analyzed the assignments of coordinators and teachers, aspects of the curriculum, and structure of teaching plans (including content and teaching methodology). The interviews were complemented or validated by information from the documents analyzed and the questionnaires.

\section{FINDINGS}

In this research, we sought to evaluate the process of teaching the discipline of scientific methodology in integrated technical courses by considering data from the interviews and documents analyzed. The results were grouped into five thematic axes: conception of scientific research, realization of scientific research integrated into high schools, criteria for choosing scientific methodology teachers, development of methodology classes and other scientific training activities, and contributions of scientific methodology and research activities to the integrated high school. These themes are elaborated below.

\section{Conception of scientific research}

We identified four categories for scientific research design: Category 1, the perspective of future work, is represented by an excerpt from a statement by S1: "Scientific research will in my opinion help us get a future job." In category 2, to deepen knowledge on a certain subject, S2 highlighted that "scientific research is used to obtain more information and knowledge about something." In category 3, project design and development, S10 reported: "For me, scientific research is something you want to design for a project. You do the research and then apply it." For category 4, resolution of everyday problems, S11 noted: "Scientific research inquires about students' scientific knowledge, leading them to research problems or hypotheses to solve these problems in their daily lives." These concepts were elaborated based on students' initial exposure with the scientific methodology in integrated high school. Based on the statements, we 
infer that the students formulated their own scientific research concepts from the understanding arising from the teaching process of this scientific training discipline.

\section{Realization of scientific research integrated into high schools}

Regarding the conduct of scientific research in the integrated high school, students, teachers, and coordinators reported some difficulties (category 1) and abilities (category 2) within their functions. For category 1, students reported having difficulties in planning, writing, and conducting research, and in the time available. Teachers reported the absence of students' reading habits, immaturity, and lack of specific methodology material in high schools. For coordinators, students and teachers' lack of time makes it difficult to conduct research. The statements below illustrate these difficulties:

"The greatest difficulty is the first contact with scientific research. This is also the first contact with the learned norms of writing, the terms used, formatting, and structure of the work [...]." (S11)

"We have some difficulty working with them (students), as this is their first contact with Scientific Methodology. It is a challenge because making a boy their age think about science is very difficult. [...], because he does not have the habit of reading [...]. A teacher here tried to adapt a workbook to suit the boys to help, and another teacher works only with ABNT (Brazilian Association of Technical Standards) [...]. Thus, it is a challenge: each one works in one way. There is no single method to work with." (SMT2)

“The greatest difficulty is these children's lack of time. [...] There are 18 to 20 subjects per year and they have classes all day. [...] We think a thousand times before putting a high school student in research. Why? Because they do not have time to dedicate to themselves." (C1)

Regarding these difficulties, the course coordinators reported seeking solutions to intensify student learning in partnership with teachers and pedagogical coordination. C3 stated: "I do a survey of the subjects students find most difficult." C1 further clarified: "I try to share a little of my experience with them of what I live and have lived in the classroom" because the pedagogical issues are working better by the pedagogical nucleus of the campus as set out in the Regulation of Technical Courses.

Regarding category (2), facilities for conducting research at an integrated high school, the participants highlighted the initial contact with the discipline of scientific methodology, and the opportunity to participate in research activities proposed by curricular components of the courses and the Institutional Program of Scientific Initiation Scholarships-High School (PIBIC-EM) offered by the educational institution. This is illustrated by the following statements:

"Last year, my teacher joined methodology and sociology and assigned us the task of scientific research involving problems in society. We then got kind of involved in the topic of homosexuality." (S6) 
"Well, I am involved in a PIBIC research project. I analyze heavy metals in the Ceres dump area. The heavy metal I am trying to analyze is cadmium, so I have a workload that I more or less have to fulfill every week in the laboratory." (S1)

"The students have this contact and then later the have the idea of getting into something, of becoming involved in something. [...]. I believe it is because of all this, because of the contact they have (with the scientific methodology), because if they did not have this first contact, they would not even know what to look for, right!" (C2)

The students gave evidence that during the methodology classes, they received guidelines for writing and developing projects individually or in groups starting from the proposal of a research project. The orientation by PIBIC supervisors occurred personally, by e-mail, and by undergraduate monitors following a schedule of activities and meetings. This is elaborated by the following statements:

"The greatest orientation we received was last year in the discipline of scientific methodology, because until then, it was very new to us [...]. Because the other teachers tell us what they have, but do not give that kind of orientation." (S2)

"The teacher guided us. It was in the classroom in some classes, give up time in class, you know. We would go to the computer and do it right. He also helped us ask questions, which we did when interviewing the campus staff." (S8)

"My supervisor guides me online. Every time I have a question, he helps me, and we have meetings where he listens to my concerns and tells me what to do. We have a schedule, and I have to conduct the activities. When I have doubts about it, he will help me and we solve them." (S12)

These transcribed statements indicate that teachers and students have difficulty in conducting scientific research in integrated high school. The process of teaching scientific methodology involves factors related to the lack of preconditions for students to develop such activities and to teachers' inexperience in working with methodological content in high school. Despite this, all participants recognize that the initial contact with the methodology in high school favors scientific research.

\section{Criteria for choosing scientific methodology teachers}

For the theme "criteria for choosing scientific methodology teachers" for integrated high school, we identified two categories of responses: (1) academic education of the teacher and prior contact with the subject, and (2) availability of the teacher. Regarding category 1, SMT2 clarified that "The scientific methodology at our institution is that everyone can work in this discipline because they have already had this training in their master's or doctorate degrees." In addition, the coordination of courses emphasizes that teachers' preparation for the methodology is related to their in-service training, that is, from the activities they create and organize in their work environment:

"Today, the criterion is that the scientific methodology teacher of the specific area of the course must have a doctorate. [...] We believe that a teacher with a doctorate has enough knowledge to teach the discipline of scientific methodology to students in a technical 
course at the school. [...] The teacher must prepare the material. When the teacher enters a new subject, he/she must prepare the lessons, gather material, and develop the didactics. As the teacher has worked on this subject [...] and has everything well organized, he/she does not want to pass the subject to anyone else. Do you understand? So, we still do not have a fixed professor of methodology [...] We are under construction." (C1)

"We are looking for a teacher who already has had some contact with the discipline or with the discipline of graduation work. Someone who comes back so that he/she has this specificity of being able to work [...]." (C2).

The teacher's availability (category 2 ) is related to their workload. The Medium Level Technical Course Regulations (2017) established that the distribution of classes (amount of hours teaching per week) and other activities related to teachers is the responsibility of the coordination of the course and teaching direction, considering the different circumstances of each course. The following statements demonstrate this distribution:

"We do not worry if a teacher publishes a lot or a little. It is more a question of logistics and of the teacher's weekly workload, and if he/she has this availability or not." (C1)

"Look, ideally, a teacher would get involved with more research and work with scientific research. However, in general, we distribute the disciplines [...] of related areas to later fill the course work of these disciplines such as scientific methodology [...]. So, it is not always the teacher who has the greatest affinity with research. Like it or not, any teacher within the IF framework is able to work with the discipline of scientific methodology. Therefore, you do not have a specific teacher, any teacher." (C3)

Interviewees' speeches indicated high teacher turnover for the scientific methodology course. It is common for teachers to change between years and even semesters. As the subject has a lower weekly workload (two hours/class) and does not require training in a specific area, it is used to supplement teachers' workload, as explained below:

"As I said, there were two teachers. I had two teachers. I did not have much ability to learn with the one teacher, but did with the second, as he worked with us on a project step-by-step. I had more ability to learn with him." (S5)

"In reality, the attribution to the subject was given to another teacher, who is an effective teacher, but when the semester had already begun, the need arose to transfer my subject [...]. He then assigned scientific methodology to me. So, what happened was an exchange of disciplines." (SMT3)

C3 also indicates there is no specific teacher for the subject:

"You change teachers every year. You do not have a specific teacher for that year. This year, for example, we already had a turnover of teachers. We started with other teachers, so there were some changes, and we had already passed the discipline to others." 
This statement highlights the need to reflect on the importance and role of the scientific methodology course in an institution with science and research as its fundamental principles.

From the statements presented, we observed that the criteria for choosing teachers hinder the teaching of scientific methodology since there is a very high turnover of teachers for the course. This makes it more difficult to prepare a teacher to work on methodology in high school.

\section{Development of methodology classes and other scientific training activities}

In the thematic axis "development of classes and contents of methodology and other activities of scientific training", we highlight two categories of responses: (1) contents necessary for research and (2) teaching procedures. For these categories, based on participants' reports, the content intended for conducting research in class in general and in the discipline of methodology in particular as well as teaching strategies were used to understand the content.

As the "contents necessary for research" (category 1), students and teachers reported the ABNT standards, construction of a research project, reading and abstract techniques, searching for material on the Internet, and guidelines for the final course work. All content comprises the discipline of scientific methodology and is common to all courses. S1 explained that "In last year's scientific methodology course, we learned the ABNT norms and several other things [...]." The following testimonials highlight other content included:

"Last year, in the discipline of scientific methodology, the teacher proposed a form of classroom activity wherein we carry out a project throughout the entire second semester. [...] The parts of the project were its rationale objective, and parts of the project itself $[\ldots] . "(\mathrm{~S} 2)$

"The construction of the project is essential, which they develop, create a theme, draft a research question, and decide how to answer that question. It does not necessarily need to be what I have been working on with them, or an unpublished question that will yield a high-impact article, for example. Important is that the process of constructing the question uses the appropriate and valid methods to answer this question." (SMT1)

"I consider the techniques of reading - namely to underline, schematize, summarize, and document the study - very important. In addition, Internet research is of databases and the technical standards of ABNT. In the case of a technician's students, it is also very important to present to them the structure of the mandatory curricular internship." (SMT3)

The methodology teachers believe students need to know the ABNT norms (specific Brazilian rules for text such as the Vancouver guidelines), but do not intend to include more than $10 \%$ of this content in the workload because "[...] regardless of whether a student primarily uses the ABNT norms, he/she has to adapt to the journal to which they will submit the work" (SMT2). The scientific content is taught by the methodology 
teacher, but can be worked on in other disciplines and activities proposed by the campus, as reported by $\mathrm{C} 1$ and $\mathrm{C} 3$.

"They (contents) can also be worked on in other disciplines, but that is up to the teacher and his plan [...]. It is in the agenda if he/she is going to use research or not. There is a teacher you like more, and one you do not like. So, it is up to the professor." (C1)

"It is worked on in the discipline of methodology. I believe that as we are also a differentiated institution, we work with extension projects, research projects, teaching projects, and the classroom [...]. However, thinking about discipline, we have [...] the discipline of course works right? [...] They reinforce what they saw in the scientific methodology, perhaps in a broader way and how it should be a work, how it is formatted, and the ABNT rules." (C3)

Teachers of other subjects consider it important for students to have knowledge about research. T2 noted: "It is important if they already know how an introduction is done, how a citation is done, how to make a bibliographic reference," because "there is no way you can develop the research without these basic contents of scientific methodology" (T1). However, they do not usually teach this content in their classes because they expect students to already have a basis from scientific methodology course. The statement below confirms this situation:

"Teachers do not talk about scientific methodology. Usually they require work, standards, and the ABNT standards, but they do not explain how these should be. Because we have already taken this subject, they hope we already know." (S2)

For category 2, teaching procedures, the participants highlighted strategies used in classes in general, especially in methodology to facilitate the learning of the content necessary for research including group activities; discussions of texts and videos; directed study; the conversation wheel; abstract practice; project preparation practice; seminars; research reports; lectures dialogued with the use of various teaching resources such as slides, texts, and printed articles; and interdisciplinary projects. The transcripts below provide some comments on the development of the classes.

"He liked to pass some texts for us to try to try to get into it, and sometimes he takes us to the computer lab for us to see the ABNT standards and others texts to learn how to report on these. After the internship, he also has to report. He also taught.” (S3)

“[...] Just yesterday we watched the film 'Lorenzo's Oil' for them to understand persistence in research and the challenges they have. I did a directed study, and posed 20 questions on top of the study based on the characteristics of scientific methodology, both pure science and the empirical method. We show, work with video, and work with discussions all the time. The first article we studied was by Volpato, 'How to write a scientific article.' We opened the wheel, read and discussed each item step-by-step, and examined the impact factors and how they relate. My proposal for the $3^{\text {rd }}$ and $4^{\text {th }}$ semesters is that each student creates a project and writes and writes: the art of writing." (SMT2) 
The dialogued expository classes used to be followed by practical activities to offer more concrete situations for students' learning through strategies that do not remain only theoretical, as explained by SMT1:

"There is still a predominance of expository classes, and I have mostly tried to work with expository classes interspersed with practical activities related to the previous class. For example, building summaries: I talk about the structure of an abstract in one lesson, and in the next, I try to work with them to build the abstract in practice. I do the same thing for the construction of a research project by following the steps and parts of a research project. In the next lesson, we do the writing. We obviously do not write an entire project, but parts thereof." (SMT1)

The development of a research project was reported to be a more dynamic activity in relation to other developed activities, and is able to provide greater learning opportunities to students by having a more practical character, as reported by $\mathrm{S} 2$ :

"In the first semester, the classes were more developed on top of the slides, articles, and so on. He showed us, explained, and discussed the various norms and terms used [...]. Then in the second semester, the teacher has already entered into a more dynamic, more practical activity, where we developed a project throughout the semester." (S2).

Regarding the development of research projects in the scientific methodology course, it is important to emphasize the importance that students have experience in research, as evident in S4's statement: "The teacher also sought to bring his experiences, bringing scientific articles that he had already done. It makes it much easier for us to see this experience, even if the teacher is working in this part of scientific research." The interviewed methodology teachers reported scientific production in 2018 and 2019, and claimed to have contact with the discipline at some point in their professional careers and continuing education. The fact that the methodology teacher has recent scientific production experience and research contact stimulates students' production of scientific knowledge. As such, we highlight the importance that the research teacher investigate his own practice and reproduce it for students' benefit when necessary.

Contributions of scientific methodology and research activities to the integrated high school

The contributions of scientific methodology and research activities to the integrated high school were divided into three categories: (1) academic background, (2) professional background and world of work, and (3) final course work. In category 1, academic training, students highlighted the development of new skills, scientific writing, and the knowledge acquired and produced. The students mentioned the relevance of initial contact with the research to exhibit the necessary knowledge in higher education, and highlighted the improvement in their writing and production of texts such as those required by the National High School Examination (ENEM), and improvement in their oratory skills. This is illustrated in the following statements:

"I consider it important even for high school that it is not integrated, because it is a subject you will take to life that will inform you scientifically, induce you to do better. 
You are going to go to college, so you need this methodology. Practice, theory, and research are fundamental and important." (S10)

"On the question of the relationship of cultured writing, the ABNT norms... An example of this in practice is the writing of the ENEM, which is an argumentative dissertation text. For example, the cultured norms of writing, such as having an introduction, objective, argument, and conclusion, whether specific or not, can help us with the issue of writing." (S11)

For teachers and coordinators, the discipline of methodology and scientific activities offer conditions to insert students into the scientific world. For C3, "when they enter a university or college, it will be the big differentiator in the room. The student has no difficulty writing a project, knows how to develop a project, knows how to participate in an event, and is differentiated." Teachers also showed that the initial contact with research in an integrated high school arouses students' interest in scientific production: "I think that this early contact with scientific methodology can arouse curiosity and criticality in terms of the curiosity of the production of scientific knowledge" (SMT1).

In category 2 , professional training, students reported contributions to the world of work through the organization of the curriculum and reflections the research provides. S15 talked about the importance of this reflection: "Many students have no idea, and the discipline begins to open their minds to research." Participation in research activities, whether in scientific initiation programs or the discipline of methodology, is regarded as preparation for students' insertion in the professional environment, as reported by S1: "It is important [...] for professional training because the labor market is very competitive today. If you do not have a good resume, excellent in fact, [...] you cannot enter the job market."

Teachers and coordinators believe that research activities provide an understanding of how information is produced and popularized, and enable the development of skills necessary for the world of work. The following statements confirm this:

"In the day-to-day of his field (student) tomorrow working in the labor market, he will have to collect data and translate this information, be it the application of fertilizer, some agrochemical, chemical defensive, whatever; he has to have this to be able to give an answer to the producer. So, this discipline helps a lot." (SMT2)

"They have no idea how important it is to know how to write a report, how to do a project, because they keep thinking: the project is just research, not research. We do projects on anything [...] and know how to set up a presentation because [...] one day, we will have to present something to someone. He/she will then have to know how to set up that presentation and behave during it. This is all covered in scientific methodology. So it is for life, not just for the scientific community, right?" (C1)

The students also reported that the research activities and content worked on in the scientific methodology course offer subsidies for carrying out the final course work (category 3). The structure of supervised internship reports and preparation of course work are part of the content of the discipline of scientific methodology in technical 
courses. S16 highlighted the importance of the elaboration of course work: "Scientific methodology will help us write the internship report, which is the last work we deliver."

The teaching of methodological content allowed students to have a broader view of everyday issues and to understand the veracity of information and applicability of methodological foundations in academic and professional life. Contact and research are part of the strategic objectives, goals, and characteristics of the IF Goiano, according to the provisions of the Institutional Development Plan (IDP) 2019-2023. The document also highlights the role of the institution in offering professional education and in the relations of knowledge with the world of work in the search for quality education. The professional education of IF Goiano prioritizes human development for the world of work and integration of teaching, research, and extension, highlighting the relevance of research for the development of society.

\section{DISCUSSION}

Based on the interviews, we made inferences regarding the development of the teaching of scientific methodology, understanding of the processes of scientific knowledge construction, and considerations regarding research activities in an integrated high school. Thus, this discussion addresses the aspects related to teaching the discipline of scientific methodology in high school based on the results of the analysis of the collected data.

\section{Understanding scientific research}

The students assigned different concepts to scientific research, using the knowledge discussed in the classroom and their own perspectives. Therefore, the discipline enabled students to master the necessary methodological principles for the appropriation of the meaning and definition of scientific research. The concepts formulated by students corroborate the definitions of authors such as Arruda (2007), Gil (2008), Lakatos and Marconi (2003), and Santos (2011), who understand scientific research as a systematic process of knowledge production to solve the daily problems of people and society using scientific procedures. Such procedures begin with the planning of research and writing of a project that needs to be developed for the researcher to reach a conclusion on a given situation or question.

When students understand scientific research as a way to get work, they believe the knowledge developed through scientific activities can provide them with better learning and differentiated training for when they enter the world of work. Regarding this, Ramos (2008, p. 9) states that "the specific process of scientific production can be constituted in a proper context of training in high school, formulating objectives, projects and pedagogical processes of scientific initiation." Thus, by allowing access to knowledge and scientific and technological principles, education enables students to make their choices and transform their reality (Ramos, 2008). Therefore, the presence of scientific methodology in high school makes students stop absorbing ready-made knowledge and start producing their own conceptions of science, technology, and the world (Moura, 2006). 


\section{Difficulties identified}

Teachers need to engage students in research practices and understand their difficulties, share their investigative work, develop activities that connect to their interests, and consider their experiences to facilitate the learning process (Severino, 2008; Lawrence et al., 2017). Here, we note that the contents of the learning needed to conduct research be worked on in an integrated high school, in some courses for the common and vocational core, and in scientific methodology. However, the students reported having difficulties in project planning, preparation, and research execution, among other aspects.

Fazenda (2000) believes these limitations are related to the lack of the habit of writing, oral communication, difficulties in interpreting scientific texts, and in the structure of the research project. According to the author, these problems are the result of inadequate training in primary education that extends to secondary education. If research activities were part of students' routine from elementary school, they would not have as many difficulties in the higher levels of education (Fazenda, 2000).

In educational practice for science journalism, Galvão et al. (2020) confirmed their participants' (undergraduate students) difficulty in writing, which resulted from a limited basic education, a worrying factor for the production of scientific knowledge. On teaching methodology and the difficulties encountered, Maia (2008) highlights the need for the intellectual preparation and skills of those who teach the discipline to ensure students understand methodological processes. The lack of understanding of methodology combined with students' difficulties such as writing and textual production interfere in the ability to carry out research activities.

\section{Teaching practice in learning scientific methodology}

To improve understanding of scientific content, teachers use various teaching strategies aimed at making learning more flexible and enhancing students' productivity. Demo (2006) highlights the importance of preparing teachers to be innovative with their methods of teaching scientific methodology, considering students' learning process and construction of their citizenship. Teachers must receive theoretical and practical training to understand the nature of scientific research and learn to deal with the problems encountered in the learning process (Bastürk, 2017; Sever et al., 2019). Maia (2008) and Moreira and Caleffe (2011) agree that appropriate strategies combined with the choice of teaching content and procedures may lead individuals to acquire habits and attitudes that benefit their professional and personal lives.

Severino (2008, p. 22) clarifies that research activities require teachers' "change of didactic-pedagogical posture" to recognize research as essential in the processes of knowledge production and teaching. As research is one of the guiding principles of comprehensive training, we emphasize the need for appreciation and greater attention to the discipline of scientific methodology. By assuming the position of a researcher, teachers begin to reflect and question their pedagogical practice and become able to develop and produce mediating actions to facilitate student learning (Maron, 2016). 
Moreira and Caleffe (2011) recognize the need of all those involved in the process to reflect on teaching practice in the discipline of scientific methodology to adapt to theoretical and practical changes in the field of research. Regarding scientific research in the school environment, Farley-Ripple et al. (2018) highlight the necessity of improving the quality of and expanding research in education so that it can offer subsidies to solve school problems in practice.

From this perspective, Groothuijsen et al. (2019) clarify that teachers conduct research on their teaching practice to seek pedagogical knowledge that can be used to solve issues inherent in the exercise of their profession. For scientific research, Demo (2010, p. 16) reports that "only those who have their own production can teach," and those that are able to write texts of their own authorship, reformulate knowledge, and redirect it to the resolution of everyday problems are qualified to teach. For Nóvoa (1999), it is not a question of offering new courses to these professionals, but of valuing their experiences and converting them into knowledge.

In this way, we believe that the situations teachers experience in the exercise of their profession inside and outside the classroom contribute to their training and need to be incorporated into teaching practices. From their experiences and reflection on the reality of the profession, teachers can create and develop their pedagogical practice (Nóvoa, 1999). Gatti (2013) agrees that teachers develop their practices based on teacher training processes and through their teaching work.

\section{Contributions of teaching methodology to high school students}

The discipline of scientific methodology is a curricular component in our evaluated courses that aims to pass on notions of scientific research to students. We observed that teachers value the initiative of having this methodology course in high school and understand that the aim is not to have students leave the integrated high school as excellent researchers, but to provide them with initial contact with research methods.

From this initial contact, we understand that students are able to develop a critical, reflective, and questioning thought process regarding their reality, which contributes to their education. The expectation is to awaken students' interest in scientific work in the academic and professional areas of the courses. Thus, scientific methodology prioritizes work as an educational principle and research as a pedagogical principle necessary for learning, because it allows the use of knowledge of basic education integrated with knowledge of specific training.

Moura (2006) shows that conducting research activities in basic education provides intellectual autonomy for students and favors academic research at more advanced levels of education. According to Moura (2006), research needs to awaken students' curiosity regarding the analysis and reconstruction of knowledge around them, enabling freedom of thought. For Freire (2002), through research, the professor allows naive curiosity to evolve from common sense to an "epistemological curiosity" that is more rigorous and closer to scientific knowledge. 
Participating in research activities provides significant experiences and benefits to students, as it allows them to critically reflect on their reality and intervene in it to become subjects of their environment and not an object or "maneuver mass" (Demo, 2006; Meydan, 2017). Thus, the differentiator of the discipline of scientific methodology is the ability to work and propose things to promote the maturation of students in their research throughout the course. Here, the contributions of research to students are related to the formation of scientific awareness for the academic activities of the technical course, preparation for higher education, and improvements for the world of work.

\section{CONCLUSIONS}

Based on a documentary analysis and interviews with students, teachers, and coordinators of technical courses, our study concludes that the teaching of the discipline promotes knowledge of methodological contents through theoretical and practical classes using different strategies. We also highlight that the teaching of scientific methodology in an integrated high school stimulates the scientific production of students, contributes to the performance of research activities, and provides comprehensive training and empowerment for students. However, despite the knowledge developed, students still have difficulties in performing scientific research activities.

In this regard, we acknowledge teachers' commitment to diversifying their teaching processes to deliver content in a way that facilitates student learning. From this perspective, we emphasize the need to provide moments of discussion and reflection between teachers of the scientific methodology of technical courses and other teaching modalities to share experiences of working with research based on daily classroom practices and research on teaching practice. Thus, we propose recommendations for the improvement of procedures and teaching material.

\section{REFERENCES}

Araújo, A. M. de L., Morais, H. C. C., Vasconcelos, H. C. A. de, Rabelo, J. C., Santos, R. X. L. dos, \& Holanda, R.-E. (2015). A pesquisa científica na graduação em enfermagem e sua importância na formação profissional. Revista de Enfermagem UFPE on Line, 9(9), 9180-9187. https://doi.org/10.5205/reuol.7874-68950-4-SM.0909201504

Arruda, G. da S. (2007). Os desafios para a iniciação científica no ensino médio integrado ao técnico. REVISTA IGAPÓ - Revista de Educação Ciência e Tecnologia Do $\begin{array}{lllll}I F A M, & \quad 3(0), & 38 . & \text { Retrieved }\end{array}$ http://www.ifam.edu.br/cms/images/file/revista_1_edicao.pdf

Bardin, L. (2016). Análise de conteúdo $\left(1^{\mathrm{a}}\right)$. São Paulo: Edições 70 Ltda - Almedina Brasil.

Bastürk, S. (2017). A different approach to the scientific research methods course: Effects of a small-scale research project on pre-service teachers. European Journal of Education Studies, 3(11), 338-359. https://doi.org/10.5281/zenodo.1063912 
Brasil, Ministério da Educação. Secretaria de Educação Profissional e Tecnológica (2007). Educação Profissional Técnica de Nivel Médio Integrada ao Ensino Médio. Retrieved from http://portal.mec.gov.br/setec/arquivos/pdf/documento_base.pdf

Brasil. Conselho Nacional de Saúde. (2012). Resolução $N^{\circ}$ 466, DE 12 de Dezembro DE 2012. Brasília.

Brasil, Ministério da Educação. Secretaria de Educação Básica. Secretaria de Educação Continuada, Alfabetização, D. e I. C. N. da E. (2013). Diretrizes Curriculares Nacionais para Educação Básica. Retrieved from http://portal.mec.gov.br/index.php?option=com_docman\&view=download\&alias=1554 8-d-c-n-educacao-basica-nova-pdf\&Itemid=30192

Demo, P. (2006). Pesquisa: princípio científico e educativo (12 $\left.2^{\mathrm{a}}\right)$. São Paulo: Cortez Editora.

Demo, P. (2010). Educação científica. Boletim Técnico Do Senac: Revista de Educação Profissional, 34(2), 1-15.

Farley-Ripple, E., May, H., Karpyn, A., Tilley, K., \& McDonough, K. (2018). Rethinking connections between research and practice in education: A conceptual framework. Educational Researcher, 47(4), 235-245. https://doi.org/10.3102/0013189X18761042

Fazenda, I. C. (2000). Dificuldades comuns entre os que pesquisam educação. In Metodologia da pesquisa educacional (6 ${ }^{\mathrm{a}}$, pp. 11-20). São Paulo: Cortez Editora.

Ferreira, C. A. L. (2015). Pesquisa quantitativa e pesquisa qualitativa: Perspectivas para o campo da educação. Revista Mosaico, 8(2), 113-121. Retrieved from http://seer.pucgoias.edu.br/index.php/mosaico/article/view/4419/2542

Filipecki, A., Barros, S. de S., \& Elia, M. da F. (2006). A visão dos pesquisadoresorientadores de um programa de vocação científica sobre a iniciação científica de estudantes de ensino médio. Ciência \& Educação (Bauru), 12(2), 199-217. https://doi.org/10.1590/s1516-73132006000200007

Freire, P. (2002). Pedagogia da autonomia: saberes necessários à prática educativa. $\left(25^{\mathrm{a}}\right)$. São Paulo: Editora Paz e Terra.

Galvão, T., Felício, C. M., Ferreira, J. C., \& Noll, M. Scientific journalism as an educational practice: An experience report of the collective construction of a "science clothesline". Science Communication, 42(2), 265-276. https://doi.org/10.1177/1075547020909467

Gatti, B. A. (2013). Educação, escola e formação de professores: políticas e impasses. Educar Em Revista, 29(50), 51-67. Retrieved from http://dx.doi.org/10.1590/S010440602013000400005

Gil, A. C. (2008). Métodos e Técnicas de Pesquisa Social (6ª ). São Paulo: Editora Atlas S.A. 
Groothuijsen, S. E. A., Bronkhorst, L. H., Prins, G. T., \& Kuiper, W. (2019). Teacherresearchers' quality concerns for practice-oriented educational research. Research Papers in Education, 1-22. https://doi.org/10.1080/02671522.2019.1633558

Hatamleh, H. M. (2016). Obstacles of scientific research with faculty of University of Jadara from their point of view. Journal of Education and Practice, 7(33), 32-47. Retrieved from www.iiste.org

Hermida, P. M. V., \& Araújo, I. E. M. (2006). Elaboração e validação do instrumento de entrevista de enfermagem. Revista Brasileira de Enfermagem, 59(1), 314-320. Retrieved from http://www.scielo.br/pdf/reben/v59n3/a12v59n3.pdf

Lakatos, E. M., \& Marconi, M. A. (2003). Fundamentos de metodologia científica (5 $)$. São Paulo: Editora Atlas S.A.

Laranjeiras, Í. C., Albuquerque, K. S. L. de S., \& Fontes, M. das G. M. S. (2011). Metodologia da Pesquisa Científica para Além da Vida Acadêmica: Apreciação de Estudantes e Profissionais Formados sobre sua Aplicabilidade na Vida Profissional. ReAC - Revista de Administração e Contabilidade. Faculdade Anísio Teixeira (FAT), Feira de Santana-Ba, 3(1), 19-31. Retrieved from http://www.fat.edu.br/reacfat.com.br/index.php/reac/article/viewFile/38/43

Lawrence, S., Jefferson, T., \& Osborn, N. (2017). Engaging students in the research process: Comparing approaches used with diverse learners in two urban high school classrooms. The Language and Literacy Spectrum, 27(1), 1-27. Retrieved from http://digitalcommons.buffalostate.edu/lls/vol27/iss1/5

Lüdke, M., \& André, M. E. D. A. (2017). Pesquisa em Educação Abordagens Qualitativas. São Paulo: Editora Pedagógica e Universitária Ltda.

Maia, R. T. (2008). A importância da disciplina de metodologia científica no desenvolvimento de produções acadêmicas de qualidade no nível superior. Revista Urutágua, (14), 1-9. Retrieved from http://www.urutagua.uem.br/014/14maia.htm \%3E

Maron, N. M. W. (2016). Os cursos de especialização do proeja e o conceito de professor pesquisador. In Educação profissional: desafios teórico-metodológicos e politicas públicas ( $1^{\mathrm{a}}$, pp. 221-244). Natal: IFRN Editora.

Medeiros, R. K. da S.; Ferreira Júnior, M. A.; Pinto, D. P. de S. R.; Vitor, A. F.; Santos, V. E. P.; \& Barichelllo, E. (2015). Modelo de validação de conteúdo de Pasquali nas pesquisas em Enfermagem. Revista de Enfermagem Referência, Série IV-(4), 127-135. https://doi.org/10.12707/RIV14009

Meydan, A. (2017). The contribution of scientific project competitions upon high school students' acquiring a scientific viewpoint (Geography lesson case). Journal of Education and Learning, 6(2), 294-304. https://doi.org/10.5539/jel.v6n2p294

Moreira, H., \& Caleffe, L. G. (2011). Os Desafios do Ensino da Disciplina de Metodologia da Pesquisa na Pós-Graduação. Meta: Avaliacao, 3(9), 244-257. 
Retrieved

from

http://revistas.cesgranrio.org.br/index.php/metaavaliacao/article/view/99/164

Moura, D. H. (2006). Reflexões sobre Ética, Estado Brasileiro e Educação. Holos, 1, 4 18. https://doi.org/https://doi.org/10.15628/holos.2006.83

Neuenfeldt, D. J., Schuck, R. J., Munhoz, A., Mittelstadt, J., Miorando, T. M., \& Rochenback, R. (2011). Iniciação à pesquisa no Ensino Superior: desafios dos docentes no ensino dos primeiros passos. Ciência \& Educação (Bauru), 17(2), 289-300. https://doi.org/10.1590/S1516-73132011000200003

Nóvoa, A. (1999). Os professores na virada do milênio : do excesso dos discursos à pobreza das práticas. Revista de Educação e Pesquisa, 11-20.

Pacheco, E. M., Pereira, L. A. C., \& Domingos Sobrinho, M. (2010). Institutos Federais de Educação, Ciência e Tecnologia: limites e possibilidades. Linhas Críticas, 16(30), 71-88. https://doi.org/10.26512/lc.v16i30.3568

Prodanov, C. C.; Freitas, E. C. (2013). Metodologia do trabalho científico $\left(2^{\mathrm{a}}\right)$. Novo Hamburgo - Rio Grande do Sul: Editora Feevale.

Ramos, M. N. (2008). Concepção do Ensino Médio Integrado. Seminário Sobre Ensino Médio Da Secretaria de Educação Do Estado Do Pará, 26. Retrieved from http://forumeja.org.br/go/sites/forumeja.org.br.go/files/concepcao_do_ensino_medio_int egrado5.pdf

Santos, E. de A. (2011). Produção Científica: Uma análise de sua contribuição na formação acadêmica e profissional dos discentes de Ciências Contábeis na Universidade Estadual de Feira de Santana. Retrieved May 7, 2018, from http://www.crcba.org.br/submissaodetrabalhos/arquivos/22092cb36f.pdf website: https://docplayer.com.br/1121938-Producao-cientifica-uma-analise-de-sua-contribuicaona-formacao-academica-e-profissional-dos-discentes-de-ciencias-contabeis-da-uefs.html

Sever, I., Öncül, B., \& Ersoy, A. (2019). Using flipped learning to improve scientific research skills of teacher candidates. Universal Journal of Educational Research, 7(2), 521-535. https://doi.org/10.13189/ujer.2019.070225

Severino, A. J. (2008). Ensino e pesquisa na docência universitária: caminhos para a integração. Retrieved January 30, 2018, from Cadernos de Pedagogia Universitária Faculdade de Educação da Universidade de São Paulo - FEUSP. website: http://www.prg.usp.br/wp-content/uploads/antonio_joaquim_severino_cadernos_3.pdf

Slessarev, Y. V., Moisseyev, V. B., \& Vostroknutov, E. V. (2015). Pedagogical conditions of ensuring students' readiness for scientific research: Example of a technical university. International Education Studies, 8(4), 150-158. https://doi.org/10.5539/ies.v8n4p150

Tosun, C. (2014). Pre-service teachers' opinions about the course on scientific research methods and the levels of knowledge and skills they gained in this course. Australian 
Journal of Teacher Education, 39(10), 96-112. https://doi.org/10.14221/ajte.2014v39n10.7

Wu, H.-L., Weng, H.-L., \& She, H.-C. (2016). Effects of scaffolds and scientific reasoning ability on web-based scientific inquiry. International Journal of Contemporary Educational Research, 3(1), 12-26. Retrieved from www.ijcer.net

Yamada, B. F. A, \& Santos, V. L. C. G. (2009). Construção e validação do Índice de Qualidade de Vida de Ferrans \& Powers: Versão feridas. Revista Da Escola de Enfermagem da USP, 43, 1105-1113. https://doi.org/10.1590/S008062342009000500015 